PublisherName : BioMed Central

PublisherLocation : London

Publisherl mprintName : BioMed Central

Luiz Antônio Barreto de Castro

Dario Grattapaglia

\title{
Investigation of cellular proliferative potential of lectin extracted from Bauhinia variegata according to different cell lines
}

\section{Articlel nfo}

ArticlelD

ArticleDOI

ArticleCitationID

ArticleSequenceNumber : 315

ArticleCategory

ArticleFirstPage

ArticleLastPage

ArticleHistory

ArticleCopyright

ArticleGrants

ArticleContext

: 1

$: 3$
: 3010

: 10.1186/1753-6561-8-S4-P265

: P265

: Poster presentation

: RegistrationDate : 2014-10-1

OnlineDate : 2014-10-1

: Reis et al.; licensee BioMed Central Ltd.2014

This article is published under license to BioMed Central Ltd. This is an Open Access article distributed under the terms of the Creative Commons Attribution License (http://creativecommons.org/licenses/by/4.0), which permits unrestricted use, distribution, and reproduction in any medium, provided the original work is properly cited. The Creative Commons Public Domain Dedication waiver ( $h$ ttp://creativecommons.org/publicdomain/zero/1.0/) applies to the data made available in this article, unless otherwise stated. 
Larissa Reis, Aff1

Corresponding Affiliation: Aff1

Caroline Rizzi, Aff1

Leonardo Monte, Aff1

J ulia Labonde, Aff1

Claudia Hartleben, Aff1

Fabrício Conceição,Aff1

Luciano Pinto, Aff1

Aff1 Center of Technology Development, Federal University of

Pelotas, Pelotas, RS 96010-900, Brazil

\section{Background}

Lectins belong to a structurally heterogeneous group of proteins that have at least one non-catalytic domain of reversible binding to specific mono-or oligosaccharides. This interaction with carbohydrates is reported in important fields such as immunology, oncology and medicine; some studies have reported the ability of these molecules in cell recognition with useful applications [1]. Seeds from leguminous plants are particularly rich in lectins and have highly homologous structures, differing mainly in their quaternaries structures, which are sufficient to provide different biological properties. The specie Bauhinia variegata belongs to the leguminous family [2]. Alencar and coworkers have demonstrated that the lectin $\mathrm{B}$. variegata has pro-inflammatory properties capable of inducing migration in vivo and in vitro of mastocyte resident cells, activating immune cells and stimulating the healing response in vivo, through fibroblasts and myofibroblast differentiation, an important event during the tissue remodeling [3]. Thus, the aim of this study is to evaluate the use of lectin extracted from Bauhinia variegata at events of cell proliferation and cytotoxicity in MDCK, NIH-3T3 and HFF1 cell lines.

\section{Methods}

The native lectin B. variegata (BVL) was extracted from seeds, according to the protocol described by Pinto et al [4]. The protein was characterized, quantified and tested for hemagglutination activity. The biological activity was evaluated by MTT (3 - (4,5-dimethylthiazol-2-yl) -2,5-diphenyltetrazolium bromide) in accordance with the strains HFF1, NHI-3T3 and MDCK. For the experiments, cells were maintained in DMEM supplemented with $10 \%$ fetal bovine serum at $37^{\circ} \mathrm{C}$ at a humidified atmosphere with $5 \%$ of $\mathrm{CO}$. The activity was evaluated with cells in logarithmic growth stage. Treatments were used at concentrations of 100,50 and $25 \mu \mathrm{g} / \mathrm{mL}$ at times of 24 and 48 hours with the HFF1 and NIH-3T3 lineages, and the time of 3 hours to MDCK lineage. 


\section{Results and conclusions}

The MTT trial was performed to detect the effect of BVL on cell proliferation and cytotoxicity. This lectin, when used in skin wounds in mice, was responsible for the epithelium reconstruction and increased keratin deposition, indicating improved wound healing [4]. Partial results of this experiment showed no cytotoxicity for the lineages tested, when compared to the control groups. After 3 hours of treatment, the BVL concentrations of 50 and $25 \mu \mathrm{g} / \mathrm{mL}$ stimulated MDCK cell proliferation. Fibroblast strains also showed proliferation at BVL presence; an increase in cell number was evidenced in $\mathrm{NIH}-3 \mathrm{~T} 3$ cells at a concentration of $25 \mu \mathrm{g} / \mathrm{mL}$ ( 24 hours) and HFF1 cells at concentrations of 100, 50 and $25 \mu \mathrm{g} / \mathrm{mL}$ (48 hours). Fibroblasts are essential to the healing of skin wounds, particularly in the early stages of healing. Stimulation of their proliferation is a mechanism that therapeutic agents may initiate repair [5]. Thus, the BVL could be used as biotechnological input, stimulating tissue healing. However, other studies will be performed as RT-PCR and flow cytometry in order to better evaluate their action mechanisms.

\section{References}

1. Komath SS, Kavitha M, Swamy MJ : Beyond carbohydrate binding: new directions in plant lectin research. Organic \& Biomolecular Chemistry. 2006, 4: 973-988. 10.1039/b515446d. doi: 10.1039/b515446d

2. Lin P, Ng TB: Preparation and biological properties of a melibiose binding lectin from Bauhinia variegata seeds. J ournal of Agricultural and Food Chemistry. 2008, 56: 10481-10486. 10.1021/jf8016332. doi: $10.1021 / \mathrm{jf} 8016332$

3. Neto LGN, Pinto LS, Bastos RM, Evaristo FFV, Vasconcelos MA, Carneiro VA, Arruda FVS, Porto ALF, Leal RB, J unior VAS, Cavada BS, Teixeira EH: Effect of the lectin of Bauhinia variegata and its recombinant isoform on surgically induced skin wounds in a murine model. Molecules. 2011, 16: 9298-9315. 10.3390/molecules16119298. doi: 10.3390/molecules16119298

4. Pinto LS, Nagano CS, Oliveira TM, Moura TR, Sampaio AH, Debray H, Pinto VP, Dellagostin OA, Cavada BS: Purification and molecular cloning of a new galactose-specific lectin from Bauhinia variegata seeds. Journal Biosciencia. 2008, 33: 355-363. 10.1007/s12038-008-0055-2.

5. Phan TT, Hughes MA, Cherry GW: Enhanced proliferation of a fibroblasts and endothelial cells treated with an extract of the leaves of Chromolaena odorata (Eupolin), an herbal remedy for treating wounds. Plastic and Reconstructive Surgery. 1998, 101 (3): 756-765. 10.1097/00006534-199803000-00027.

This PDF was created after Publication. 